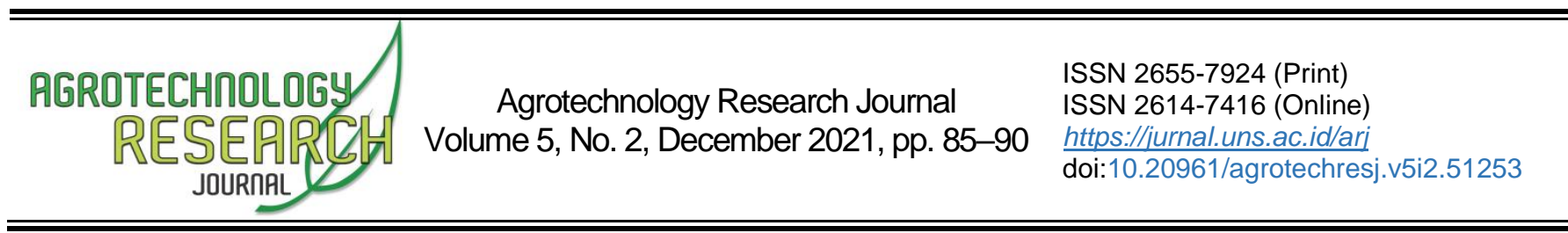

\title{
Keanekaragaman Vegetasi Pohon pada Lahan Pekarangan di Desa Tambakrejo Kecamatan Jombang Kabupaten Jombang
}

\section{Diversity of Tree Vegetation on Yard Land in Tambakrejo Village, Jombang District, Jombang Regency}

\author{
Indah Fitriani ${ }^{1}{ }^{*}$, Nur Faisal Andani ${ }^{2}$, Anggi Indah Yuliana $^{3}$, Ahmad Syaifudin $^{4}$ \\ 1,2Department of Agrotechnology, Faculty of Agriculture, Universitas KH. A. Wahah Hasbullah, Jombang, Jawa Timur 61419, \\ Indonesia
}

Received 15 May 2021; Accepted 24 October 2021; Published 31 December 2021

\begin{abstract}
Tambakrejo Village is an urban area located in the Jombang District. Tree vegetation continues to decline; one of the factors is the conversion of the function of yardland to residential areas. Changes in the land area will impact the structure of tree vegetation. This research was conducted by purposive sampling in 4 hamlets. Transects and species were included as random effects using the transect quadrat method (quadrat transect) by purposive sampling with tree size $\left(10 \times 10 \mathrm{~m}^{2}\right)$. The data analysis was done qualitatively and quantitatively. Quantitative data analysis using vegetation analysis, namely: Importance Value Index (IVI), Dominance (C), and Diversity Index $(\hat{\mathrm{H}})$. Strata 3 tree vegetation $\mathrm{H}^{\prime}$ index in Tambakrejo Village, each hamlet is different, for Tambakberas Hamlet, $\mathrm{H}^{\prime}$ index value is $3.11 \%$, Gedang Hamlet 2.97\%, Nglungu Hamlet 2.91\%, and for Petengan Hamlet 2, 89\%. Most of the hamlets in Tambakrejo Village fall into medium-level diversity. INP index of Tambakberas Hamlet of $22.59 \%$ and lowest $2.07 \%$. Gedang of $27.57 \%$ and lowest $2.84 \%$, Nglungu of $19.76 \%$, and lowest $2.86 \%$ Petengan of $28.79 \%$ and lowest $2.73 \%$, The lowest Important Value Index is due to the transfer of the function of yard land for residential areas.
\end{abstract}

Keywords: diversity; dominance; importance value index

Cite this as (CSE Style): Fitriani I, Andani NF, Yuliana Al, Syaifudin A. 2021. Keanekaragaman vegetasi pohon pada lahan pekarangan di Desa Tambakrejo Kecamatan Jombang Kabupaten Jombang. Agrotechnology Res J. 5(2):85-90. https://dx.doi.org/10.20961/agrotechresj.v5i2.51253.

\section{INTRODUCTION}

Desa Tambakrejo merupakan salah satu contoh daerah urban yang berada di Kecamatan Jombang dengan kepadatan penduduk paling tinggi $6,88 \mathrm{jiwa} / \mathrm{km}^{2}$ dengan jumlah penduduk 12.279 jiwa (BPS Jombang 2020). Kepadatan penduduk juga mengindikasikan kebutuhan akan ruang rumah atau permukiman juga meningkat (BPTP Aceh 2015). Hal ini dapat berkembang ke arah perluasan rumah dan pembukaan lahan baru atau alih fungsi lahan untuk permukiman. Perubahan luasan akan berdampak pada perubahan struktur vegetasi pohon. Semakin padat penduduk maka semakin rendah indeks keanekaragaman dan kemerataan tanaman di suatu daerah (Fajarwati et al. 2020).

Kepadatan penduduk dapat mempengaruhi pertumbuhan pohon, tutupan kanopi, keanekaragaman tumbuhan bawah. Efeknya bervariasi menurut umur tegakan, yaitu perkembangan tegakan.(Zhang et al.

${ }^{*}$ Corresponding Author:

E-Mail': ifitriani597@gmail.com
2016). Untuk menekan dampak dari kepadatan penduduk maka dapat dilakukan upaya pemanfaatan lahan pekarangan dapat menciptakan pelestarian lingkungan hidup terutama tanaman lokal, selain itu peranan dan pemanfaatan pekarangan bervariasi dari satu daerah ke daerah lainnya, hal ini tergantung pada tingkat kebutuhan, sosial budaya, tingkat pendidikan, faktor fisik serta ekologi setempat (Zufahmi et al. 2020). Pekarangan berkaitan erat dengan lanskap produksi pekarangan dengan tanaman buah/pohon (Ali et al. 2020).

Jumlah penduduk di Desa Tambakrejo mengalami peningkatan setiap tahunya, menyebabkan lahan pekarangan mengalami penyusutan termasuk pohonpohon yang berada di pekarangan. Pohon terus menerus mengalami kemerosotan, salah satu faktornya adalah alih fungsi lahan pekarangan menjadi pemukiman penduduk (Irwan et al. 2018). Untuk mengetahui dampak potensi vegetasi pohon di suatu kawasan maka diperlukan adanya analisis vegetasi pohon (strata 3, 2-4 m).

Analisis vegetasi adalah suatu cara mempelajari susunan dan komposisi vegetasi secara bentuk (komunitas) vegetasi tumbuhan, indeks yang dihitung 
yaitu kerapatan relatif, kerapatan mutlak, frekuensi relatif, frekuensi mutlak, dominansi relatif, dominansi mutlak dan indeks nilai penting (Prasetyo 2006). Analisis vegetasi berfungsi untuk memperoleh data kuantitatif tentang struktur dan komposisi suatu komunitas tumbuhan (Sari et al. 2018). Berdasarkan penelitian yang telah di lakukan di kawasan pantai Nipah Pulo Aceh Kabupaten Aceh besar di temukan 15 spesies tumbuhan strata pohon dari 12 famili. Nilai indeks keanekaragaman vegetasi tumbuhan tersebut yaitu 1,729 yang tergolong ke dalam keanekaragaman sedang (Maghfirah et al. 2020).

Berdasarkan uraian untuk mengetahui keberadaan suatu spesies pohon akibat alih fungsi lahan dan dampak kepadatan penduduk maka diperlukan sebuah upaya identifikasi vegetasi pada suatu wilayah mendorong untuk dilakukannya penelitian tentang lahan pekarangan mengenai keanekaragaman vegetasi pohon, yang berguna untuk pengembangan potensi desa terutama pada tanaman komoditas pekarangan di Desa Tambakrejo Kecamatan Jombang Kabupaten Jombang Jawa Timur.

\section{BAHAN DAN METODE}

Penelitian ini dilakukan secara purposive berdasarkan ketersediaan data dan informasi di lapang sebanyak 68 sampel. Parameter yang diamati adalah semua jenis tumbuhan strata 3 dengan ketinggian 2-4 m (Septiawan et al. 2018) yang berada di Desa Tambakrejo (Gambar 1).

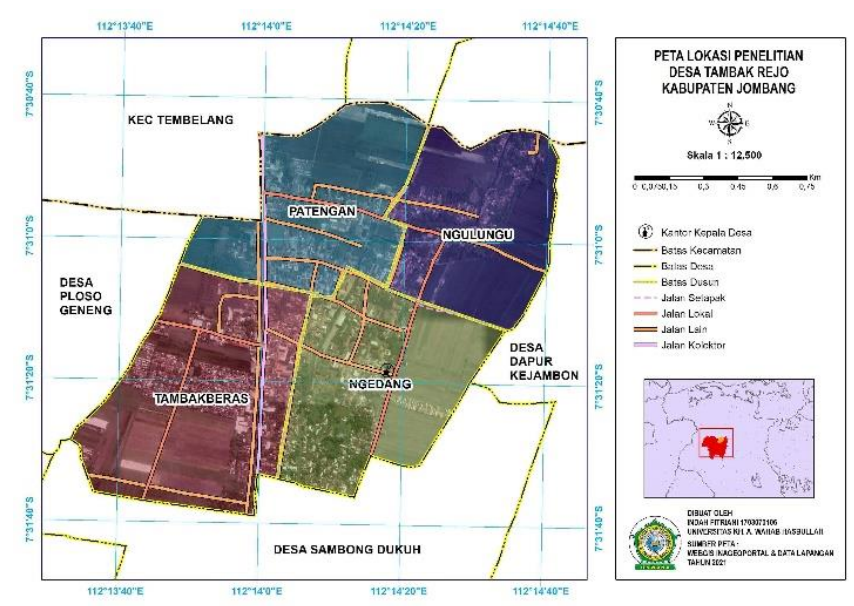

Gambar 1. Lokasi Penelitian

Sumber : Webgis Image portal dan Data Lapangan 2021

Alat yang digunakan dalam penelitian ini adalah Alat tulis, Kamera, meteran gulung . Bahan yang digunakan adalah buku tulis, Lembar Pengamatan, Plot $10 \times 10 \mathrm{~m}$, dan vegetasi pohon pekarangan yang terdapat di lokasi penelitian. Vegetasi suatu tanaman dianalisis dengan kuantitatif dilakukan untuk menjelaskan keanekaragaman dan struktur vegetasi. Vegetasi tumbuhan yang dilakukan dengan cara mencari Indeks Nilai Penting (INP), dan Indeks Keanekaragaman

Kerapatan Relatif (KR) (Komul et al. 2013)

$\mathrm{KR}=\frac{\text { Kerapatan Suatu Jenis }}{\text { Kerapatan Seluruh Jenis }} \mathrm{X} 100 \%$
Frekuensi Relatif (FR) (Feriatin 2017)

$F R=\frac{\text { Frekuensi Suatu Jenis }}{\text { Frekuensi Petak Seluruhnya }} \times 100 \%$

Indeks Nilai Penting (INP) (Junaidah et al. 2017)

$\mathrm{INP}=\mathrm{KR}+\mathrm{FR}$

Indeks Keanekaragaman Shannon Wiener (H') (Sirait et al. 2018)

$\mathbf{H}^{\prime}=-\sum \mathbf{P i} \ln \mathbf{P i}$.

$H^{\prime}$ : Indeks keanekaragaman Shannon-Wiener

$\mathrm{Pi}$ : Proporsi jumlah individu ke-i (ni/N)

ni : Kelimpahan spesies ke-i

$\mathrm{N}$ : Kelimpahan total spesies yang ditemukan

$\Sigma$ : Jumlah

Hasil $H^{\prime}$ yang diperoleh dihubungkan dengan kategori indeks keanekaragaman. Kategori Indeks Keanekaragaman (Odum 1993) pada Tabel 1.

Tabel 1. Kategori indeks keragaman

\begin{tabular}{ll}
\hline Kategori & $\begin{array}{l}\mathrm{H}^{\prime}(\text { Indeks } \\
\text { Keanekaragaman })\end{array}$ \\
\hline Keanekaragaman tinggi & $>3,00$ \\
Keanekaragaman sedang & $1,00-3,00$ \\
Keanekaragaman rendah & $<1,00$ \\
\hline
\end{tabular}

Indeks Dominansi (C)

$\mathrm{C}=\frac{n i}{N}$

Keterangan: C: Indeks Dominansi Simpson; ni: INP dari spesies ke-l; $\mathrm{N}$ : Kelimpahan total spesies yang ditemukan

Menurut Odum (1993) bahwa kisaran nilai indeks Dominansi $(C)$ yaitu antara 0-1. Nilai indeks Dominansi (C) jika mendekati 0 berarti tidak ada jenis yang mendominansi, namun jika nilai indeks. Dominansi (C) mendekati 1 maka terdapat jenis yang mendominansi (Sutrisna et al. 2018).

\section{HASIL DAN PEMBAHASAN}

Hasil penelitian menunjukkan indeks keanekaragaman di Desa Tambakrejo berbeda satu dengan yang lain. Berdasarkan Gambar 2 Dusun Tambakberas dengan indeks keanekaragaman sebesar 3,11, Dusun Gedang indeks keanekaragaman sebesar $2,97 \%$, Dusun Nglungu dengan indeks keanekaragaman sebesar 2,91\%, Dusun Petengan dengan indeks keanekaragaman sebesar 2,89\%. Tingkat keanekaragaman yang paling tinggi terdapat pada Dusun Tambakberas. Jumlah pohon yang ditemukan sebanyak 36 jenis pohon dengan jumlah pohon sebanyak 125 dan jumlah total indeks keragaman 3,11\% dihubungkan dengan kategori indeks keanekaragaman $<3,00$ keanekaragaman tinggi. Hal ini dikarenakan pada Dusun Tambakberas mayoritas penduduk masih memiliki pekarangan yang luas dan masyarakatnya masih ada upaya untuk memanfaatkan lahan pekarangan untuk ditanami. Indeks Keanekaragaman 
terendah berada di Dusun petengan, yang salah satu faktornya mayoritas lahan yang dimiliki telah beralih fungsi menjadi pemukiman.

Berdasarkan Gambar 2 Indeks dominasi (C) di Desa Tambakrejo menunjukkan hasil yang berbeda disajikan. Tambakberas nilai Indeks Dominasi sebesar 0,04, Dusun Gedang Indeks Dominasi sebesar 0,08, Dusun Nglungu Indeks Dominasi sebesar 0,11, dan Indeks Dominasi Dusun Petengan sebesar 0,08. Pohon mangga gadung (Mangifera indica L) yang banyak ditemukan di pekarangan penduduk Desa Tambakrejo dengan nilai $\mathrm{C}$ rata-rata dari ke empat dusun sebesar 0,92 . Dominansi merupakan nilai yang menunjukkan penguasaan suatu jenis terhadap jenis lain dalam suatu komunitas, makin besar nilai dominasi suatu jenis makin besar pengaruh penguasaan jenis tersebut terhadap jenis lain. (Mariana dan Warso 2016).

Indeks keanekaragaman dapat digunakan sebagai bio indikator yang menggambarkan dukungannya terhadap kestabilan sebuah ekosistem. Besar kecilnya nilai indeks keanekaragaman tanaman di pekarangan dapat memberi petunjuk seberapa besar daya dukungan ekosistem terhadap pemukiman (Yulianti et al. 2018). Hasil ini menunjukkan bahwa Nilai Indeks Dominansi (C) pekarangan adalah $<1$, artinya tanaman pekarangan yang terdapat dalam lokasi penelitian tidak dikuasai oleh satu jenis, daerah yang memiliki nilai dominasi $>1$ maka keanekaragamannya rendah. Tata kelola lingkungan menjadi salah satu faktor utama dalam ketersediaan keanekaragaman pohon yang melimpah, konservasi hayati harus berdasarkan ekosistem yang mendukung serta masyarakat yang ikut berperan aktif (Primmer et al. 2017).

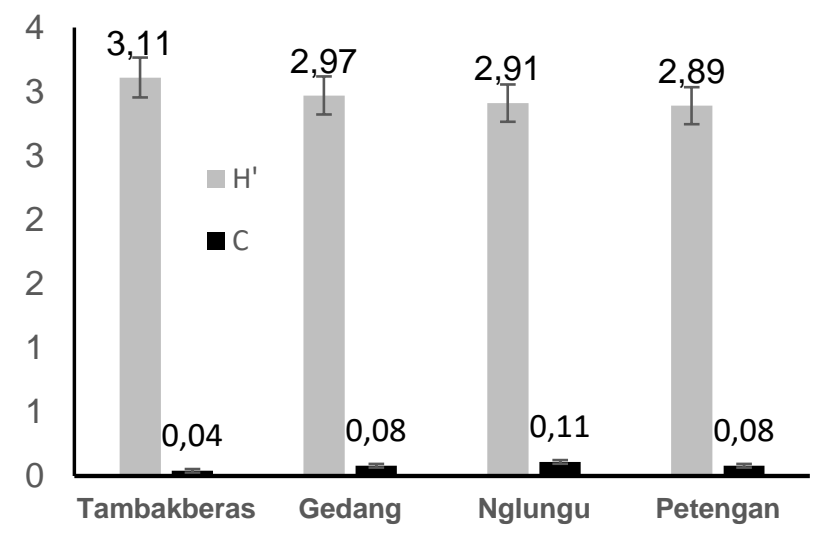

Gambar 2. Diagram keanekaragaman $H^{\prime}$ dan Indeks Dominansi C Vegetasi Pohon Di Desa Tambakrejo Kecamatan Jombang Kabupaten Jombang

Tabel 2 menunjukkan Indeks Nilai Penting tertinggi di Dusun Tambakberas terdapat pada varietas mangga gadung (Mangifera indica L) dengan nilai sebesar $22,59 \%$ dengan total 14 individu. Sedangkan untuk Indeks Nilai Penting terendah terdapat pada varietas buah tin (Ficus carica), coklat (Theobroma cacao), durian (Durio), jambu darsono (Sizigyium malaccense), jambu Kristal (Psidium guajava (I) merr), jambu merah (Psidium guajava linn), jeruk bali (Citrus maxima), jeruk nipis (Citrus $\times$ aurantiifolia), juwet (Syzygium cumin), kembang turi (Sesbania grandiflora), ketepeng (Senna alata), kurma (Phoenix dactylifera), mangga sepat (Mangifera indica L), matoa (Pometia pinnata), muris (Annona muricata), radu (Ceiba pentandra) dan trembesi (Samanea saman) dengan Indeks Nilai Penting sebesar $2,07 \%$ yang setiap varietasnya terdapat 1 individu.

Tabel 2. Keanekaragaman vegetasi pohon dusun Tambakberas

\begin{tabular}{|c|c|c|c|c|}
\hline No. & Nama Lokal & Nama IImiah & $\boldsymbol{\Sigma}$ & INP(\%) \\
\hline 1 & Alpukat & Persea americana & 4 & 8,26 \\
\hline 2 & Belimbing & Averrhoa carambola & 4 & 7,00 \\
\hline 3 & Buah tin & Ficus carica & 1 & 2,07 \\
\hline 4 & Coklat & Theobroma cacao & 1 & 2,07 \\
\hline 5 & Durian & Durio & 1 & 2,07 \\
\hline 6 & Gadung & Dioscorea hispida & 6 & 6,07 \\
\hline 7 & Jambu biji & Psidium guajava & 3 & 6,20 \\
\hline 8 & $\begin{array}{l}\text { Jambu } \\
\text { darsono }\end{array}$ & Sizigyium malaccense & 1 & 2,07 \\
\hline 9 & Jambu kristal & $\begin{array}{l}\text { Psidium guajava (I) } \\
\text { merr }\end{array}$ & 1 & 2,07 \\
\hline 10 & Jambu merah & Psidium guajava linn & 1 & 2,07 \\
\hline 11 & Jeruk bali & Citrus maxima & 1 & 2,07 \\
\hline 12 & Jeruk nipis & Citrus $\times$ aurantiifolia & 1 & 2,07 \\
\hline 13 & Juwet & Syzygium cumini & 1 & 2,07 \\
\hline 14 & Kelengkeng & Dimocarpus longan & 8 & 15,26 \\
\hline 15 & Kembang turi & Sesbania grandiflora & 1 & 2,07 \\
\hline 16 & Keres & Muntingia calabura & 3 & 3,67 \\
\hline 17 & Kesemek & Diospyros kaki & 2 & 2,87 \\
\hline 18 & Ketepeng & Senna alata & 1 & 2,07 \\
\hline 19 & Kluwih & Artocarpus camansi & 7 & 8,13 \\
\hline 20 & Kurma & Phoenix dactylifera & 1 & 2,07 \\
\hline 21 & Lamtoro & $\begin{array}{l}\text { Leucaena } \\
\text { leucocephala }\end{array}$ & 4 & 7,00 \\
\hline 22 & $\begin{array}{l}\text { Mangga } \\
\text { gadung }\end{array}$ & Mangifera indica L & 14 & 22,59 \\
\hline 23 & $\begin{array}{l}\text { Mangga } \\
\text { kopyor }\end{array}$ & Mangifera indica L & 2 & 2,87 \\
\hline 24 & $\begin{array}{l}\text { Mangga } \\
\text { manalagi }\end{array}$ & Mangifera indica L & 2 & 4,13 \\
\hline 25 & $\begin{array}{l}\text { Mangga } \\
\text { podang }\end{array}$ & Mangifera indica L & 20 & 22,33 \\
\hline 26 & Mangga sepat & Mangifera indica L & 1 & 2,07 \\
\hline 27 & Matoa & Pometia pinnata & 1 & 2,07 \\
\hline 28 & Muris & Annona muricata & 1 & 2,07 \\
\hline 29 & Nangka & $\begin{array}{l}\text { Artocarpus } \\
\text { heterophyllus }\end{array}$ & 5 & 10,33 \\
\hline 30 & Pucuk merah & Syzygium paniculatum & 3 & 3,67 \\
\hline 31 & Rambutan & Nephelium lappaceum & 11 & 17,66 \\
\hline 32 & Randu & Ceiba pentandra & 1 & 2,07 \\
\hline 33 & Sawo & Manilkara zapota & 4 & 5,73 \\
\hline 34 & Srikaya & Annona squamosa & 3 & 6,20 \\
\hline 35 & Sukun & Artocarpus altilis & 3 & 4,93 \\
\hline \multirow[t]{2}{*}{36} & Trembesi & Samanea saman & 1 & 2,07 \\
\hline & & & $\begin{array}{l}12 \\
5\end{array}$ & 200,00 \\
\hline
\end{tabular}

Keterangan: $\Sigma=$ Jumlah Individu; $C=$ Dominansi; INP= Indeks Nilai Penting 
Indeks nilai penting didapatkan dari hasil Kerapatan Relatif (KR) ditambah hasil Frekuensi Relatif (FR) setiap varietas yang terdapat pada lokasi penelitian. Indeks Nilai Penting jenis tanaman menunjukkan bahwa tanaman tersebut memiliki peranan dan manfaat bagi kehidupan masyarakat (Ahmad et al. 2016). Semakin besar nilai INP suatu jenis pohon maka semakin besar tingkat penguasaan terhadap sehabitatnya dan sebaliknya. Penguasaan jenis tertentu dalam suatu habitat apabila jenis yang bersangkutan berhasil menempatkan sebagian besar sumber daya yang ada dibandingkan dengan spesies yang lainnya (Hidayat 2017). Dusun Gedang ditemukan sebanyak 28 jenis pohon dengan total 83 individu disajikan pada Tabel 3.

Tabel 3 menunjukkan Indeks Nilai Penting tertinggi di Dusun Gedang terdapat pada varietas mangga gadung (Mangifera indica L) dengan nilai sebesar 27,57\% dengan total 12 individu. Sedangkan untuk Indeks Nilai penting terendah terdapat pada varietas alpukat (Persea americana), anggur (Vitis vinivera), daun salam (Syzygium polyanthum), delima (Punica granatum), jambu merah (Psidium guajava linn), jeruk buah (Citrus sp), kamboja (Adenium obesum), kenikir (Cosmos caudatus), mahoni (Swietenia mahagoni), mangga manalagi (Mangifera indica L), manggis (Garcinia mangostana), muris (Annona muricata), randu (Ceiba pentandra), dan trembesi (Samanea saman) dengan Indeks Nilai Penting sebesar 2,84\% yang setiap varietasnya terdapat 1 individu.

Indeks Nilai Penting dan indeks dominasi merupakan indikator yang menentukan keanekaragaman suatu komunitas yang ditemukan pada petak penelitian. Mangga gadung banyak ditemukan karena memiliki peranan dan manfaat untuk dikonsumsi maupun dijual oleh masyarakat, sehingga masyarakat banyak yang membudidayakan juga didukung perawatan pohon mangga mudah dilakukan Tetapi untuk Dusun Gedang tidak ada pohon yang mendominasi karena untuk setiap spesies yang ditemukan $<1$. Dusun Nglungu terdapat 24 jenis pohon dengan total 77 individu disajikan pada Tabel 4.

Tabel 4 menunjukkan Indeks Nilai Penting tertinggi di Dusun Nglungu terdapat pada varietas mangga gadung (Mangifera indica L) dengan nilai sebesar $19,76 \%$ dengan total 8 individu. Sedangkan untuk Indeks Nilai Penting terendah terdapat pada varietas pohon asem (Tamarindus indica), daun salam (Syzygium polyanthum), jambu jamaika (Syzygium malaccense), keres (Muntingia calabura), randu (Ceiba pentandra), ringin (Ficus benjamina) dan sukun (Artocarpus altilis) dengan nilai sebesar $2,86 \%$ yang setiap varietasnya terdapat 1 individu.

Indeks nilai penting untuk beberapa spesies yang ditemukan dikategorikan rendah karena adanya alih fungsi lahan pekarangan untuk pemukiman penduduk, sehingga pohon yang dinilai tidak memiliki nilai ekonomis tinggi dan tidak berguna maka akan dilakukan penebangan. Kepadatan penduduk juga dapat mempengaruhi pertumbuhan tumbuhan tingkat bawah, apabila tidak stabil maka bahan bakar dimasa depan menjadi terancam (Zhang et al. 2016). Dusun Petengan terdapat 25 jenis pohon dengan total 103 individu disajikan pada Tabel 5.
Tabel 5 menunjukkan Indeks Nilai Penting tertinggi di Dusun Petengan terdapat pada varietas mangga gadung (Mangifera indica L) dengan nilai sebesar $28,79 \%$ dengan total 17 individu. Sedangkan untuk Indeks Nilai Penting terendah terdapat pada varietas pohon alpukat (Persea americana), jeruk nipis (Citrus), kapas (Gossypium), mangga manalagi (Mangifera indica L), murbei (Mangifera indica L), dan randu (Ceiba pentandra) dengan nilai sebesar $2,73 \%$.

Indeks nilai penting juga dipengaruhi oleh lanskap yang ditemukan pada lahan penelitian. Lanskap di Desa Tambakrejo termasuk dataran rendah, jenis tanah lempung berpasir, sedikit bebatuan dengan sumber air yang cukup melimpah. Pengembangan lanskap produksi tanaman pekarangan perlu adanya upaya dukungan dari pemerintah daerah setempat, partisipasi dari warga juga adanya pembelajaran dengan pendamping. (Van der Sluis et al. 2019).

Tabel 3. Keanekaragaman vegetasi pohon dusun Gedang

\begin{tabular}{|c|c|c|c|c|}
\hline No. & Nama Lokal & Nama IImiah & $\Sigma$ & INP (\%) \\
\hline 1 & Alpukat & Persea americana & 1 & 2,84 \\
\hline 2 & Anggur & Vitis vinivera & 1 & 2,84 \\
\hline 3 & Belimbing & Averrhoa carambola & 3 & 8,53 \\
\hline 4 & Daun salam & Syzygium polyanthum & 1 & 2,84 \\
\hline 5 & Delima & Punica granatum & 1 & 2,84 \\
\hline 6 & Jambu air & Syzygium aqueum & 2 & 5,69 \\
\hline 7 & Jambu biji & Psidium guajava & 3 & 8,53 \\
\hline 8 & $\begin{array}{l}\text { Jambu } \\
\text { merah }\end{array}$ & Psidium guajava linn & 1 & 2,84 \\
\hline 9 & Jeruk & Citrus $s p$ & 1 & 2,84 \\
\hline 10 & Jeruk nipis & Citrus $\times$ aurantiifolia & 4 & 11,38 \\
\hline 11 & Kamboja & Adenium obesum & 1 & 2,84 \\
\hline 12 & Kelengkeng & Dimocarpus longan & 7 & 13,35 \\
\hline 13 & Kenikir & Cosmos caudatus & 1 & 2,84 \\
\hline 14 & Keres & Muntingia calabura & 2 & 4,05 \\
\hline 15 & Lamtoro & Leucaena leucocephala & 7 & 16,63 \\
\hline 16 & Mahoni & Swietenia mahagoni & 1 & 2,84 \\
\hline 17 & $\begin{array}{l}\text { Mangga } \\
\text { gadung }\end{array}$ & Mangifera indica $\mathrm{L}$ & 12 & 27,57 \\
\hline 18 & Mangga & Mangifera indica $\mathrm{L}$ & 1 & 2,84 \\
\hline 19 & $\begin{array}{l}\text { Mangga } \\
\text { podang }\end{array}$ & Mangifera indica $\mathrm{L}$ & 7 & 10,07 \\
\hline 20 & Manggis & Garcinia mangostana & 1 & 2,84 \\
\hline 21 & Muris & Annona muricata & 1 & 2,84 \\
\hline 22 & Nangka & Artocarpus heterophyllus & 6 & 13,79 \\
\hline 23 & Rambutan & Nephelium lappaceum & 7 & 8,40 \\
\hline 24 & Randu & Ceiba pentandra & 1 & 2,84 \\
\hline 25 & Sirsak & Annona muricata & 3 & 6,89 \\
\hline 26 & Srikaya & Annona squamosa & 3 & 8,53 \\
\hline 27 & Sukun & Artocarpus altilis & 3 & 8,53 \\
\hline 28 & Trembesi & Samanea saman & 1 & 2,84 \\
\hline
\end{tabular}

Keterangan: $\Sigma=$ Jumlah Individu; $C=$ Dominansi; INP= Indeks Nilai Penting 
Tabel 4. Keanekaragaman vegetasi pohon dusun Nglungu

\begin{tabular}{|c|c|c|c|c|}
\hline No & Nama Lokal & Nama IImiah & $\Sigma$ & INP (\%) \\
\hline 1 & Asem & Tamarindus indica & 1 & 2,86 \\
\hline 2 & Belimbing & Averrhoa carambola & 7 & 18,47 \\
\hline 3 & Blinjo & Gnetum gnemon & 2 & 4,16 \\
\hline 4 & Daun Salam & Syzygium polyanthum & 1 & 2,86 \\
\hline 5 & Jambu air & Syzygium aqueum & 5 & 14,31 \\
\hline 6 & Jambu jamaika & Syzygium malaccense & 1 & 2,86 \\
\hline 7 & Jambu kluthuk & Psidium guajava & 2 & 4,16 \\
\hline 8 & Jambu merah & Psidium guajava linn & 2 & 5,72 \\
\hline 9 & Jati & Tectona grandis & 2 & 4,16 \\
\hline 10 & Jeruk & Citrus $s p$ & 3 & 7,02 \\
\hline 11 & Jeruk nipis & Citrus $\times$ aurantiifolia & 3 & 8,58 \\
\hline 12 & Kelengkeng & Dimocarpus longan & 7 & 18,47 \\
\hline 13 & Kenikir & Cosmos & 2 & 5,72 \\
\hline 14 & Keres & Muntingia calabura & 1 & 2,86 \\
\hline 15 & Lamtoro & Leucaena leucocephala & 6 & 15,60 \\
\hline 16 & Mangga gadung & Mangifera indica $\mathrm{L}$ & 8 & 19,76 \\
\hline 17 & Mangga podang & Mangifera indica L & 2 & 5,72 \\
\hline 18 & Nangka & Artocarpus heterophyllus & 7 & 16,90 \\
\hline 19 & Rambutan & Nephelium lappaceum & 7 & 16,90 \\
\hline 20 & Randu & Ceiba pentandra & 1 & 2,86 \\
\hline 21 & Ringin & Ficus benjamina & 1 & 2,86 \\
\hline 22 & Sirsak & Annona muricata & 1 & 2,86 \\
\hline 23 & Srikaya & Annona squamosa & 4 & 11,44 \\
\hline 24 & Sukun & Artocarpus altilis & 1 & 2,86 \\
\hline
\end{tabular}

Keterangan: $\Sigma=$ Jumlah Individu; $C=$ Dominansi; INP= Indeks Nilai Penting

\section{KESIMPULAN}

Indeks keanekaragaman vegetasi pohon strata 3 di Desa Tambakrejo setiap dusunnya berbeda-beda, untuk Dusun Tambakeberas nilai indeks keanekaragamannya sebesar 3,11\% , Dusun Gedang sebesar 2,97\% ,Dusun Nglungu sebesar 2,91\% , dan untuk Dusun Petengan sebesar 2,89\%. sebagian besar Dusun yang ada di Desa Tambakrejo masuk dalam kategori keanekaragaman tingkat sedang yang ditemukan pada varietas pohon mangga gadung (Mangifera indica L) sehingga perlu adanya upaya konservasi hayati untuk mempertahankan pohon asli daerah setempat.

\section{DAFTAR PUSTAKA}

Ahmad H, Roini C, Ahsan S. 2016. Analisis struktur vegetasi pada habitat kupu-kupu Papilio Ulysses $\mathrm{Di}$ Pulau Kasiruta. J Bioedukasi. 4(2):1689-1699.
Tabel 5. Keanekaragaman vegetasi pohon dusun Petengan

\begin{tabular}{|c|c|c|c|c|}
\hline No & Nama Lokal & Nama IImiah & $\Sigma$ & INP (\%) \\
\hline 1 & Alpukat & Persea americana & 1 & 2,73 \\
\hline 2 & Belimbing & Averrhoa carambola & 4 & 10,90 \\
\hline 3 & Coklat & Theobroma cacao & 2 & 3,70 \\
\hline 4 & Jambu Air & Syzygium aqueum & 3 & 8,18 \\
\hline 5 & Jambu Darsono & $\begin{array}{l}\text { Sizigyium } \\
\text { malaccense }\end{array}$ & 5 & 6,61 \\
\hline 6 & Jambu Klampok & $\begin{array}{l}\text { Sizigyium } \\
\text { samarangense }\end{array}$ & 3 & 6,42 \\
\hline 7 & Jambu Merah & Psidium guajava linn & 2 & 5,45 \\
\hline 8 & Jati & Tectona grandis & 3 & 4,67 \\
\hline 9 & Jeruk Nipis & Citrus & 1 & 2,73 \\
\hline 10 & Kapas & Gossypium & 1 & 2,73 \\
\hline 11 & Kelengkeng & Dimocarpus longan & 4 & 10,90 \\
\hline 12 & Keres & Muntingia calabura & 4 & 5,64 \\
\hline 13 & Kluwih & Artocarpus camansi & 2 & 5,45 \\
\hline 14 & Lamtoro & $\begin{array}{l}\text { Leucaena } \\
\text { leucocephala }\end{array}$ & 13 & 19,64 \\
\hline 15 & Mangga Gadung & Mangifera indica $\mathrm{L}$ & 17 & 28,79 \\
\hline 16 & $\begin{array}{l}\text { Mangga } \\
\text { Manalagi }\end{array}$ & Mangifera indica L & 1 & 2,73 \\
\hline 17 & Mangga Podang & Mangifera indica L & 4 & 9,15 \\
\hline 18 & Murbei & Morus alba $\mathrm{L}$ & 1 & 2,73 \\
\hline 19 & Nangka & $\begin{array}{l}\text { Artocarpus } \\
\text { heterophyllus }\end{array}$ & 7 & 15,57 \\
\hline 20 & Rambutan & $\begin{array}{l}\text { Nephelium } \\
\text { lappaceum }\end{array}$ & 6 & 12,84 \\
\hline 21 & Randu & Ceiba pentandra & 1 & 2,73 \\
\hline 22 & Sawo & Manilkara zapota & 2 & 5,45 \\
\hline 23 & Sengon & Albizia chinensis & 6 & 7,58 \\
\hline 24 & Srikaya & Annona squamosa & 3 & 6,42 \\
\hline 25 & Sukun & Artocarpus altilis & 7 & 10,30 \\
\hline & Jumlah & & 103 & 200,00 \\
\hline
\end{tabular}

Keterangan: $\Sigma=$ Jumlah Individu; $C=$ Dominansi; INP= Indeks Nilai Penting

Ali MS, Arifin HS, Arifin NHS. 2020. Dinamika pekarangan Kampung Selahuni 2 , Desa Ciomas Rahayu, Bogor. J Nat Resour Environ Manag. 10(3):364-373. http://dx.doi.org/10.29244/jpsl.10.3.364-373.

[BPS Jombang] Badan Pusat Statistik Jombang. 2020. Kecamatan Jombang Dalam Angka 2020. Jombang (ID): Badan Pusat Statistik Kabupaten Jombang.

[BPTP Aceh] Balai Pengkajian Teknologi Pertanian Aceh. 2015. Petunjuk teknis. Aceh (ID): Balai Pengkajian Teknologi Pertanian Aceh.

Fajarwati FK, Hadisusanto S, Hartono H. 2020. Hubungan kerapatan penduduk dengan keanekaragaman tanaman buah pekarangan $\mathrm{Di}$ Kecamatan Godean, Kabupaten Sleman, Yogyakarta. J Mns Lingkung. 27(2):50-59. https://doi.org/10.22146/jml.53401. 
Feriatin. 2017. The diversity of garden plants and their utilization for supporting food security the sub district of South Wakorumba. J Ilmu Pertan Indones. 22(2):99-107. https://doi.org/10.18343/jipi.22.2.99.

Hidayat M. 2017. Analisis vegetasi dan keanekaragaman tumbuhan di kawasan manifestasi Geotermal le Suum Kecamatan Mesjid Raya Kabupaten Aceh Besar. J Biot. 5(2):114-124. https://doi.org/10.22373/biotik.v5i2.3019.

Irwan SNR, Rogomulyo R, Trisnowati S. 2018. Pemanfaatan pekarangan melalui pengembangan lanskap produktif di Desa Mangunan, Kabupaten Bantul Yogyakarta. J Ilmu Pertan Indones. 23(2):148-157. https://doi.org/10.18343/jipi.23.2.148.

Junaidah J, P.Suryanto PS, Budiadi B. 2017. Komposisi jenis dan fungsi pekarangan (Studi kasus desa Giripurwo, Kecamatan Girimulyo, DI Yogyakarta). J Hutan Trop. 4(1):77. https://doi.org/10.20527/jht.v4i1.2884.

Komul YD, Sahupalla A, Irwanto I. 2013. Struktur dan komposisi hutan alam dataran rendah dan perbukitan pada wilayah kecamatan teon nilai serua Pulau Seram, Kabupaten Maluku Tengah. J Makila. $7(2): 15-30$.

Maghfirah A, Aini A, Agustinawati, Mulyadi, Fakhri. 2020. Analisis vegetasi tumbuhan strata pohon di kawasan pantai nipah Pulo Aceh Kabupaten Aceh Besar. Dalam: Kamal S, Mulyadi. Pandemi Covid-19: tantangan pendidikan dan research di era new normal. Prosiding Seminar Nasional Biotik VIII 2020; 30 Juli 2020. Banda Aceh (ID): Program Studi Pendidikan Biologi, Fakultas Tarbiyah Dan Keguruan Universitas Islam Negeri Ar-Raniry. 8: 1-6.

Mariana, Warso F. 2016. Analisis komposisi dan struktur vegetasi untuk menentukan indeks keanekaragaman di Kawasan Hutan Kota Pekanbaru. J Bio-Lectural. 3(2):90-96.

Odum EP. 1993. Dasar-dasar ekologi. Samingan T, penerjemah. Srigandono B, editor. Yogyakarta (ID): Gadjah Mada University Press.

Prasetyo B. 2006. Struktur komunitas dan profil vegetasi dalam sistem pekarangan di desa Jabon Mekar, Kecamatan Parung, Bogor [Tesis]. Bogor(ID): IPB University.

Primmer E, Termansen $M$, Bredin $Y$, Blicharska $M$, García-Llorente M, Berry P, Jääskeläinen T, Bela $G$, Fabok V, Geamana N, et al. 2017. Caught between personal and collective values: biodiversity conservation in European decision-making. Environ
Policy Gov.
https://doi.org/10.1002/eet.1763.

Sari DN, Wijaya F, Mardana MA, Hidayat M. 2018. Analisis vegetasi tumbuhan bawah dengan metode transek (line transect) di kawasan hutan Deudap Pulo Aceh Kabupaten Aceh Besar. In: Prosiding Seminar Nasional Biotik. Dalam: Pemanfaatan riset biodiversitas dalam pembelajaran biologi berbasis karakter dan lingkungan menuju revolusi 4.0. Prosiding Seminar Nasional Biotik VI 2018; 19 Juli 2018. Banda Aceh (ID): Program Studi Pendidikan Biologi, Fakultas Tarbiyah Dan Keguruan Universitas Islam Negeri Ar-Raniry. 6:165-173.

Septiawan W, Indriyanto I, Duryat D. 2018. Species, density, and canopy stratification of social forestry of the farmers group rukun makmur 1 in register 30 Mount Tanggamus Lampung. J Sylva Lestari. $5(2): 88$.

Sirait M, Rahmatia F, Pattulloh. 2018. Komparasi indeks keanekaragaman dan indeks dominasi Fitoplakton Di Sungai Ciliwung Jakarta. J Kelaut Indones J Mar Sci Technol.

https://doi.org/10.21107/jk.v11i1.3338. 11(1):75.

Van der Sluis T, Arts B, Kok K, Bogers M, Busck AG, Sepp K, Loupa-Ramos I, Pavlis V, Geamana N, Crouzat E. 2019. Drivers of european landscape change: stakeholders' perspectives through Fuzzy Cognitive Mapping. Landsc Res. 44(4):458-476. https://doi.org/10.1080/01426397.2018.1446074.

Sutrisna T, Umar MR, Suhadiyah S, Santosa S. 2018. Keanekaragaman dan komposisi vegetasi pohon pada kawasan air terjun Takapala dan Lanna di Kabupaten Gowa Sulawesi Selatan. J Biol Makassar. 3(1):12-18. https://doi.org/10.20956/bioma.v3i1.4258.

Yulianti D, Purnama AA, Brahmana EM. 2018. Keanekaragaman tanaman pekarangan di desa tambusai timur kecamatan Tambusai Kabupaten Rokan Hulu Provinsi Riau. J Sainstek. 10(2):13-19.

Zhang J, Young DH, Oliver WW, Fiddler GO. 2016. Effect of overstorey trees on understorey vegetation in California (USA) ponderosa pine plantations. Forestry. 89(1):91-99. https://.doi.org/10.1093/forestry/cpv036.

Zufahmi, Dewi E, Mulinda. 2020. Keanekaragaman jenis tumbuhan pekarangan yang terdapat di Pemukiman Lueng Putu Kecamatan Bandar Baru Kabupaten Pidie Jaya. J Agroristek. 3(2):44-50. https://doi.org/10.47647/jar.v3i2.258. 